\title{
11
}

\section{Cultivating global citizenship in engineering courses}

\author{
Alejandra Boni, Penny MacDonald \\ and Jordi Peris
}

\section{Introduction}

-aking into account the context of uncertainty and change which lies ahead for most engineering graduates in their professional lives, numerous experts and higher education bodies not only demand a solid knowledge of the technical aspects of the profession, they also see the need to introduce the so-called soft skills that lie at the interface of physical sciences and humanities/social sciences (Cruickshank and Fenner, 2007). Among these, we highlight reflexivity (Robbins, 2007), creativity, communication and leadership (Sheppard et al, 2009) and the ethical competences (Newberry, 2004; Billington, 2006; Berjano and Boni, 2009).

We understand that these ethical competences should be applied to the discussion concerning individual awareness of the values which have a direct influence on the carrying out of one's profession, but also that they should address global ethical dilemmas. As Sheppard et al point out, it is important to understand the micro and macro ethical dimensions of professional practice:

even if graduates are not expected to move into positions that involve policy formulation and other direct macro-ethical decision making, the large perspective provides an important context that should play a role in shaping many aspects of micro-ethical professional practice. (2009:138) 
Along similar lines, the United States-based Accreditation Board for Engineering and Technology (2008) proposes that as a result of professional training programmes in the field of engineering, the outcomes should include: an understanding of professional and ethical responsibility; the broad education necessary to understand the impact of engineering solutions in a global, economic, environmental, and societal context; and a knowledge of contemporary issues.

In this chapter we give a detailed account of the rationale and development of a subject in the curriculum which has been offered since 1995 to engineering undergraduates at the Universidad Politécnica de Valencia (UPV), Spain. It aimed to enhance three ethical abilities considered to be of utmost importance in the formative process of professional engineers. According to moral philosopher Martha Nussbaum, these three abilities are fundamental to cultivating humanity in educational contexts (Nussbaum, 1997). The abilities proposed by Nussbaum are the following:

The capacity for critical examination or critical thinking:

Is particularly crucial for good citizenship in a society that needs to come to grips with the presence of people who differ by ethnicity, caste and religion [...] training this capacity requires developing the capacity to reason logically, to test what one reads or says for consistency of reasoning, correctness of fact, and accuracy of judgment

The second, cosmopolitan ability, focuses on:

Understanding the differences that make understanding difficult between groups and nations and the shared human needs and interests that make understanding essential, if common problems are to be solved [which includes] the related task of understanding differences internal to one's own nation

And, finally, the narrative imagination:

This means the ability to think what it might be like to be in the shoes of a person different from oneself, to be an intelligent reader of that person's story, and to understand the emotions and wishes and desires that someone so placed might have. (Nussbaum, 2006:38891)

In Nussbaum's proposition we have discovered a source of inspiration that has helped us construct a humanistic university curriculum pedagogically based on development education. Thus education can be understood as a formative process whose main goal is to empower learners through a teaching and learning process which develops knowledge, skills and values to 
enable them to become members of a global community of equals (Boni, 2006). This vision of development education reflects what is known as fifth generation development education, which particularly emphasises a global perspective (Mesa, 2000; Ortega, 2008).

This curricular experience involves two subjects: Introduction to Development Cooperation and Development Aid Projects, which are offered as free elective courses with a length of 45 to 60 hours per course depending on the school where they are taught. In this chapter we describe the origins and context in which the experience has evolved over the years, the objectives and teaching methodology and the results of an exploratory study carried out between 2005 and 2007. The study aimed to determine whether, and to what extent, the students developed a more critical spirit which would allow them to adopt a more global and cosmopolitan vision of the world.

\section{A curriculum to foster global citizenship abilities}

In 1995 a group of students and professional engineers involved with a nongovernmental development organisation (NGDO) named Engineers without Borders started an innovative course on development aid. With the endorsement of The Technical School of Industrial Engineering, Valencia, and support from the Department of Engineering Projects, the first lecture on development aid in a Spanish engineering environment took place. Over a ten-year period, more than 3,000 undergraduate students followed two free elective courses one on introductory issues regarding development and development aid called Introduction to Development Aid and the other entitled Development Aid Projects. The aim of this initiative was to develop in future professionals a sense of democratic and global citizenship through the accomplishment of the following objectives:

to bring the University closer to the reality of southern countries, thereby overcoming prejudice and revealing the consequences of individual actions and personal and professional attitudes to that reality

- to contribute to the acquisition of a global and interdependent vision of the reality in which students will develop their future professional activities

- to encourage active social involvement, volunteering and professional activity oriented towards social action.

Table 11.1 provides a summary of the main concepts these two elective courses dealt with, from the point of view of the teaching-learning process. 


\begin{tabular}{|c|c|c|}
\hline $\begin{array}{l}\text { Knowledge and } \\
\text { Understanding }\end{array}$ & Skills & Attitudes and Values \\
\hline $\begin{array}{l}\text { social justice and equality } \\
\text { globalisation and } \\
\text { interdisciplinarity } \\
\text { kinds of development } \\
\text { diversity } \\
\text { peace and conflict } \\
\text { development aid } \\
\text { cosmopolitan citizenship }\end{array}$ & $\begin{array}{l}\text { critical thinking } \\
\text { ability to argue effectively } \\
\text { cooperation and conflict } \\
\text { resolution } \\
\text { ability to challenge } \\
\text { injustices and inequality }\end{array}$ & $\begin{array}{l}\text { empathy } \\
\text { sense of identity and self } \\
\text { esteem } \\
\text { value and respect for } \\
\text { diversity } \\
\text { commitment to social } \\
\text { justice and equity } \\
\text { sensitive to environmental } \\
\text { issues and committed to } \\
\text { sustainable development } \\
\text { firm belief that people can } \\
\text { make a difference } \\
\text { capacity for self-regulation }\end{array}$ \\
\hline
\end{tabular}

\section{Table 11.1: summary of contents}

Methodologically, we do not underplay the importance of technical content in the curriculum, but we regard the key approach needed to foster a student's cosmopolitan ability as being how they learn rather than what they learn. For instance, if we want to enhance critical thinking or a commitment to social justice and equity when explaining human development theories, after a short overview of these theories' key issues we spend more time discussing in groups how the concept of human development can be applied in our context and our lives. To do this, we use the matrix of needs and satisfiers proposed by Max Neef et al (1994) to allow students to understand the contextual, multicultural and non-Eurocentric sense of human development.

Using the technique of moral dilemma to introduce reflections on a controversial issue in development is a further example of the importance of how learning is facilitated. One such dilemma concerns the tension between social audits for fair trade products - for example, carpet making - and the context in which these products are made - for instance, using child labour. After presenting the dilemma we use open and respectful dialogue to trigger a series of arguments - such as whether or not to sell the carpets on fair trade circuits (Lozano et al, 2006). We use these two exercises to foster Nussbaum's abilities; namely, a person's critical and autonomous capacity and their ability to think for themselves. We thus discourage a-critical forms of thinking on development or simplistic approaches to resolving complex, moral problems, and promote socially responsible and reflective choices. We also foster respect, 
dignity and recognition, as well as social relations that promote attitudes of active respect, listening and sensitivity to others which thus avoid dogmatic egocentrism.

Another ability our lectures aim to foster is the competence to challenge inequalities. In this sense, critical reflection on global issues such as globalisation, migration and environmental problems are illustrated with examples of how change happens. This is a strategic point in the course. To overcome the widespread belief in the impossibility of challenging the trends of the globalisation process, we focus on the importance of personal and collective agency, using examples of champions and networking that have made changes in the world possible (Chambers and Pettit, 2004). We comment on successful global campaigns such as the International Campaign to Ban Landmines, global boycotts against products manufactured with child labour and the World Social Forum in our lectures.

One of the most remarkable insights afforded by this experience of learning and teaching is owed to the strong connection between the University and NGDOs in Valencia. For many who work in the broad field of development, the statistics of the World Bank or even the Human Development Report are seen as a privileged form of knowledge. Universities in the North rarely have the chance to create opportunities for their students to be immersed in contexts of poverty and marginalisation in the South, where experiences of life differ from their own and alternative perceptions about knowledge may arise. To address this, those of us working in universities in the North open our lectures to people from other parts of the world, allowing our students, through the interactions and dialogues that ensue, to perceive new realities. These revelations happen often and are almost always new and frequently unexpected.

Moreover, we offer the possibility of a brief immersion in Valencia's local context through short internships in NGDOs. From 1995 to 2008, 189 students have had this practical experience in sixteen of the city's NGDOs (Calabuig and Gómez-Torres, 2008), contributing to each organisation in some of the following ways: teaching basic computer courses, developing short studies for development aid projects and accompanying disabled people. The majority of students considered the experience extremely positive as they became acquainted with different problems and contexts and overcome prejudices about such people as gypsies, migrants or former inmates of secure institutions (Boni, 2007). This kind of experiential learning (Kolb, 1984) fosters students' cosmopolitan abilities alongside their emotional qualities of empathy, understanding, awareness and discernment. 


\section{Fostering global citizenship? Results of an exploratory study}

Between 2005 and 2007, we carried out an exploratory study which aimed to ascertain whether there was any evidence in the students' discourse to indicate their development of the abilities described by Nussbaum. We are aware that these abilities are not exclusively process-related, since they reflect values and question beliefs and ideologies. Moreover, these abilities can obviously be acquired not only within but also beyond the confines of the classroom. Accordingly, we consciously refer to this study as exploratory, and maintain that its main objective was to determine whether the educational intervention actually contributed to the learners developing Nussbaum's abilities.

To facilitate this the following questions were presented to the students before they started the course: What does the term 'development' mean to you? How do you think your values, beliefs, and attitudes influence your idea of development? And vice versa, how do you think you can have an influence on development issues? Students' reflections were written down and the same questions were repeated at the end of the course. To prevent influencing the answers given it was made clear that they were not being evaluated or included in the final mark.

Through quantitative and qualitative analysis of the students' responses in the pre- and post-course questionnaires, we were able to deconstruct the discourse in search of clues which might indicate some tentative development of critical thinking, cosmopolitan ability and narrative imagination. The written task required the students to externalise their inner thoughts and concerns, to put on paper their ideas and preconceptions concerning the issues that surround the concept of development in a changing world. There were a total of 80 informants, 37 female students and 43 male. Their nationalities were Spanish (63), Colombian (8), French (5), German (2), Australian (1) and Polish (1). The questionnaires were hand-written in Spanish and then transcribed. An analysis of the students' discourse was carried out using both quantitative and qualitative methods. The initial quantitative analysis was facilitated by using tools from the field of corpus linguistics ${ }^{1}$ to identify the different aspects of lexis, grammar and the use of language in the texts. After making frequency word lists and carrying out concordances using the programme WordSmith 5 (Scott, 1996a), the next stage involved the study of longer parts of the texts.

Evidence showed clearly that students wrote significantly more about the different issues in the post-course questionnaires. Compared to the pre-course questionnaires, 50 per cent more words were used in the texts. While a direct link cannot be established between the development of critical thinking and 
the length of the texts written, it does suggest that students had more to say, were more informed about the different topics and had more confidence to write in the later exploratory survey about the different questions brought up during the course. Moreover, a closer analysis of what was written in the texts suggests that while students critically examined the main issues relating to development and globalisation, they also placed themselves and their roles and responsibilities to society, both globally and locally, under the microscope too.

The most frequent content words in both the pre- and post- questionnaires are: development, country or countries and life. The most notable differences involved the words north, sustainable and human. In the post-course questionnaire, however, the last word is used 35 times next to the term development, whereas it only appears twice in the pre-course questionnaires. While the post-course questionnaires reveal notable differences concerning the students' perceptions of development, they also illustrate the complexity, richness and rigour of their arguments which reflect critical thought by not simply centering on economic issues. Students instead considered development as being dependent on multiple factors, as for instance:

Development involves several different aspects such as the economy, education, employment, housing, trade balance, technology, etc providing the population with quality of life, and the nation with sustainable growth, and is generated by the correct use and administration of a country's assets and resources.

In the same way, while the term sustainable appears only five times in the pre-course questionnaires, in the post-course text there are 50 incidences of its use, collocating with such terms as development, welfare, and environment. This not only highlights the increase in the use of these tokens, it shows there has been a qualitative change in the students' reflections. This is incorporated in the following statement: 'I am now familiar with the term sustainable development, a way of growing without harming...'

Students are not only aware that the welfare system is unsustainable, they also admit that the same is true of their personal growth within the consumer society they are immersed in: 'I think that living in a consumer society, my personal development is unsustainable.'

Concerning the issue of an action-oriented approach as a component of the global citizenship ability for tackling common problems, in the pre-course questionnaires students were generally quite negative about their capacity to change the status quo. In some cases, their attitude depended on the different 
governments in power - some said, for example, 'everything is in the hands of the USA and the European Allies' or 'I think I have very little influence on development.'

By the end of the course participants appear to have acquired a more global and interdependent vision of their roles in striving for a fairer society. They seem to have become empowered individuals who know they can influence what is happening through individual and collective action. They state, for instance: 'therefore I can have some influence on the development of other countries, even though it is only on a small scale'; or 'we have seen quite clearly in this subject that there are many ways of taking action, of helping in the field of development.'

By using certain forms more in the post-course questionnaires, the students illustrate their growing involvement, at both personal and collective level, in the search for solutions to problems in the field of development and other complex issues concerning human relations on a global scale. Discourse analysts study the use of modality in texts as it often reveals what the writer's own perspective, attitude or stance is through the use of certain verbs, adjectives and adverbs. Unlike the nouns we analysed above, which appeared with a higher frequency, the verbs 'supposed', 'think', 'guess' and 'believe' were less frequent in the post-course questionnaires. Given that most would have had only a working knowledge of the different issues involved in the field of development, we understand that students would have been less confident about what they were writing about before taking the course.

According to Quirk et al, modal verbs, such as those indicating permission, obligation and volition, involve some kind of intrinsic human control over events (1987:219). In the case of 'must', two main uses have been established: logical necessity and obligation or compulsion. We have found in our data that nearly all the different forms of 'must' are used in the texts, although the present tense third person singular ('must') and first person plural ('we must') are used much more frequently in the post-course questionnaires - indeed, there are nearly five times as many examples of its use in this case. This frequency expresses what Quirk et al (1987:225) call obligation or compulsion, since there is an implication that the speaker or writer is 'advocating a certain form of behaviour' which indicates that the actual order of things in the world must be changed. There is a further implication that certain actions are seen as imperative, but the use primarily expresses that a person is to be found within the confines of those actions, as indicated by the pronoun 'we'. The student is thus indicating a higher degree of personal implication as part of 
the process of developing a global citizenship. Examples from students include: 'that is why we should work in many different ways, joint projects'; or 'to finish, I think we also must change the way we act with the countries in the South'.

If they are to acquire a narrative imagination, people have to understand what it is, and what it feels like to be the 'other'. The terms North and South are used significantly more in the post-course questionnaires. Appearing four and 45 times in the pre- and post-course questionnaires respectively, the increase in the use of the term North suggests that the course made students more aware of the North-South divide, so that by the end more appreciated that where one is born determines so many factors related to an individual's well-being - and that, ultimately, development is an issue that should concern people as much in the North as it does in the South. Their comments reflect these views: 'I can confirm that a person's social condition and the place where he or she is born will directly affect his or her idea of what development is'; 'I think that this is a key concept: by reducing the existing inequalities between South and North many of the problems will be resolved in the South ...'

Pronoun use in some genres has been strongly associated with the creation of social identities and the different social relations which can be established between writers and readers and the broader context being referred to in the texts. These features of reader-writer visibility are used to express attitudes and feelings and create greater interaction with the reader. As a consequence they can provide insights into the narrative imagination and empathy of the writer in relation to the other actors who are mentioned in the texts.

In Spanish (the language used by all the students in this survey, although not necessarily their native tongue), personal pronouns are less frequently used than they are in English. As a sign of grammatical person and number especially with verbs, they tend to be shown in the form of verbal morphemes (MacDonald, 2005). Studying the use of personal pronouns in critical discourse analysis enables the analyst to distinguish which groups the writers belong to, which are distanced from them, which pronouns indicate 'inclusion' and which are used (whether intentionally or not) for 'exclusion'.

It is interesting that although the majority clearly identify themselves with the rich and affluent North, they show their criticism of this individual and collective 'we' and display strong empathy with the other, or those who were born in the poorer parts of the world: the South. This is clearly expressed by a 
student who said: 'We are getting richer all the time, and they are getting poorer; this situation, if it continues, will explode...'

Many of the students in their post-course questionnaires remark how taking the subject has radically changed their attitude, not only with regards to development issues but also in relation to myriad subtler matters concerning their own moral consciences, their values and the possibilities each has for bringing about changes - they are now much more positive. As they put it: 'at the beginning of the course I really felt I had little influence on the topic of development. Now I really believe I can do something, both on a personal and professional level'; or: 'the world seems a smaller place [after working on, and thinking about the issue of development] and at the same time, your power to influence becomes greater.'

\section{Conclusion}

In this chapter we have discussed the rationale, pedagogy and outcomes of a curriculum offered to engineering students at the Universidad Politécnica de Valencia (Spain). The curriculum comprises two elective subjects entitled Introduction to Development Aid and Development Aid Projects. The inspiration for the construction of the curriculum was the three democratic abilities proposed by Nussbaum $(1997 ; 2006)$ and the way to operationalise it was development education understood as education for global citizenship. From our analysis of the discourse of the students, we can conclude that they did indeed develop the abilities described by Nussbaum; firstly, because of the complexity, richness and rigour of their arguments and reflections, or critical thinking; secondly, in the way they express their understanding of difference, the feeling of global identity and their orientation to action, ie cosmopolitan ability; and lastly, in their empathy for and awareness of the problems of others, or their narrative imagination. In the same way, although there may not be a significant relation between taking these subjects and the acquisition of critical skills for bringing about social transformation, we can confirm that many students showed clear indications of becoming empowered, being made aware of their capabilities and knowing they can influence what is happening, not only at the present time but also when they finish their studies and have an opportunity to put these cosmopolitan abilities into practice in their professional lives.

\section{Acknowledgements}

We wish to thank Clive Carthew for proofreading this chapter. 


\section{CULTIVATING GLOBAL CITIZENSHIP IN ENGINEERING COURSES}

\section{Note}

1 Corpus linguistics is the term that is used to define the approach or methodology which studies language use by gathering samples of what is actually said or written (a corpus), using computer technology for its analysis.

\section{References}

Accreditation Board for Engineering and Technology (2008) Criteria for accrediting engineering programs. Effective for evaluations during the 2009-2010 accreditation cycle

http://www.abet.org/Linked\%20Documents-UPDATE/Criteria\%20and\%20PP/E001\%200910\%20EAC\%20Criteria\%2012-01-08.pdf (January 2012)

Billington, D P (2006) Teaching ethics in engineering education through historical analysis. Science and Engineering Ethics (12) 205-22

Boni, A (2006) La educación universitaria: Hacia el desarrollo humano? In A Boni and A PerezFoguet (eds) Construir la ciudadanía global desde la universidad. Intermon-Oxfam: Barcelona

Boni, A (2007) Las asignaturas 'Introducción a la Cooperación para el Desarrollo’ y ‘Proyectos de Cooperación al Desarrollo'. 10 años impulsando procesos de aprendizaje críticos y transformadores en la universidad in Ferrero, G, Monzo, J M and Gómez, M (eds) Un proceso de aprendizaje: experiencias de cooperación para el Desarrollo en la UPV. Valencia: Universidad Politécnica de Valencia

Boni, A and Berjano, E (2009) Ethical learning in higher education. The experience of Technical University of Valencia. European Journal of Engineering Education 34(2) 205-13

Calabuig, C and Gómez-Torres, M (2008) Prácticas de Participación Social en ONG: una experiencia de Educación para el Desarrollo en el marco de enseñanzas técnicas universitarias. Paper presented at IV ${ }^{\circ}$ Congreso Universidad y Cooperación, 12-14 November in Universidad Autónoma de Barcelona, Spain

Chambers, R and Pettit, J (2004) Shifting power to make a difference. In L Groves and R Hinton (eds) Inclusive Aid: changing power and relationships in international development. London: Earthscan

Cruickshank, $\mathrm{H}$ and Fenner, R (2007) The evolving role of engineers: toward sustainable development of the built environment. Journal of International Development 19 111-21

Freire, P (1970) Pedagogía del Oprimido. Madrid: Siglo XXI

Grundy, S. (1991) Producto o Praxis del Currículum. Madrid: Morata

Kolb, D (1984) Experiential Learning: experience as a source of learning and development. Englewood Cliffs NJ: Prentice Hall

Lozano, J F, Palau-Salvador, G, Gozálvez, V and Boni, A (2006) The use of moral dilemmas for teaching agricultural engineers. Science and Engineering Ethics 12(2) 327-34

Macdonald, P (2005) An analysis of interlanguage errors in sychronious/ asyncronous interculturlal communication exchanges. Publicacions de la Universitat de Valencia: Valencia

Max-Neef, M, Elizalde, A and Hopenhayn, M (1994) Desarrollo a Escala Humana. Barcelona: Icaria Mesa, M (2000) La educación para el desarrollo: entre la caridad y la ciudadanía global. Papeles de Cuestiones Internacionales 70 11-26

Newberry, B (2004) The dilemma of ethics in higher education. Science and Engineering Ethics 10 343-51

Nussbaum, M (1997) Cultivating Humanity. A classical defense of reform in liberal education. Cambridge: Harvard University Press

Nussbaum, M (2006) Education and democratic citizenship: capabilities and quality education. Journal of Human Development 7(3) 385-95 
HIGHER EDUCATION FOR THE PUBLIC GOOD: VIEWS FROM THE SOUTH

Ortega, M L (2008) Estrategia de la Cooperación Española de Educación para el Desarrollo Madrid: Ministerio de Asuntos Exteriores y de Cooperación

Quirk, R, Greenbaum, S, Leech, G. and Svartik, J (1987) A Comprehensive Grammar of the English Language. London: Longman

Robbins, P T (2007) The reflexive engineer: perceptions of integrated development. Journal of International Development 19 99-110

Sheppard, S D, Macatangay, K, Colby, A and Sullivan, W M (2009) Educating Engineer. Designing for the future of the field. Jossey-Bass and The Carnegie Foundation: San Francisco 